\title{
Article \\ Compost Functions as Effective Replacement for Peat-Based Potting Media in Organic Greenhouse Transplant Production
}

\author{
Tsuzuchi Isaka, Sean Clark*(i) and Janet Meyer \\ Department of Agriculture and Natural Resources, Berea College, Berea, KY 40404, USA; \\ isakat@bereaalumni.org (T.I.); meyerj@berea.edu (J.M.) \\ * Correspondence: clarks@berea.edu
}

Citation: Isaka, T.; Clark, S.; Meyer, J. Compost Functions as Effective Replacement for Peat-Based Potting Media in Organic Greenhouse Transplant Production. J 2021, 4 , 394-403. https://doi.org/10.3390/ j4030030

Academic Editor: Mario A. Pagnotta

Received: 9 July 2021

Accepted: 1 August 2021

Published: 5 August 2021

Publisher's Note: MDPI stays neutra with regard to jurisdictional claims in published maps and institutional affiliations.

Copyright: (c) 2021 by the authors. Licensee MDPI, Basel, Switzerland. This article is an open access article distributed under the terms and conditions of the Creative Commons Attribution (CC BY) license (https:/ / creativecommons.org/licenses/by/ $4.0 /)$.

\begin{abstract}
Commercial horticulture in many regions of the world depends upon Sphagnum peat as a potting-media substrate, but extracting peat has serious environmental consequences. Composts may be able to serve as effective substitutes for peat and offer potential environmental advantages. The suitability of compost as potting media depends upon the raw materials as well as processing methods used. This study includes two related experiments-one with beet (Beta vulgaris L.) and the other with tomato (Solanum lycopersicum L.) —aimed at assessing the potential viability of farmproduced, food-residuals compost as a replacement for peat-based potting media in the production of organic vegetable transplants. The experiments were conducted in 2021 on the Berea College Farm in Kentucky, USA, a USDA certified organic farm. The results indicated that potting media composed of $75 \%$ to $100 \%$ compost performed as well as fertilized, peat-based growing media for plant growth. Further, although weeds were present in the compost, weed pressure was not severe enough to adversely affect crop growth. Thus, sterilization of compost, which did eliminate weeds in the compost, was not deemed necessary for using the compost as a partial or complete potting medium. Compost pasteurization was also assessed but was ineffective in destroying weed seeds.
\end{abstract}

Keywords: compost; food residuals; potting media; peat; organic horticulture; sustainable agriculture; vegetable production

\section{Introduction}

The composition of potting media is an important factor that affects the overall performance of the transplants and crops. In the modern commercial horticultural industry, Sphagnum peat is widely used as a potting-media substrate for its preferable characteristics such as low bulk density, good drainage, absence of weed seeds and pathogens, and relatively low cost of production [1]. On the other hand, the process of extracting peat, which involves clearing the vegetation from the site, draining the bog, and harvesting decomposing peat moss, poses significant environmental challenges including destruction of wildlife habitat and increased carbon emissions $[2,3]$. It is estimated that while peatland covers only $3 \%$ of the total land area, it stores one-third of soil carbon on the Earth [4]. Extraction of peat therefore leads to increases in carbon emissions which contributes to climate change.

Use of compost has been investigated by various researchers as a potential peat substitute in horticulture. Compost is estimated to have lower greenhouse gas emissions and require that less commercial mineral fertilizer be added to potting media [5]. Suitability of composts as potting media depends on the raw materials and processing methods used to produce them. A study by Farrell and Jones [6] reported that compost derived from a mixture of food residuals and green wastes could replace peat-based potting media by $75 \%$ while not affecting plant growth negatively. According to a study by Clark and Cavigelli [7], food-residuals compost performed as well as fertilized peat-based potting media, while compost derived from horse bedding performed poorly due to high salinity. 
Another study by Lazcano et al. [8] showed that when compost derived from cow manure replaced more than $50 \%$ of peat-based potting media for tomato plants, it led to immediate plant mortality due to the high bulk density and salinity of the compost. They also noted that vermicompost derived from pig manure performed well even when it was used as a $100 \%$ substitution for peat-based potting media. By utilizing locally available composts that have acceptable levels of soil nutrients and salinity, farms may be able to increase the overall sustainability of the production system.

A drawback to using composts as potting media, however, is the potential for higher weed pressure. Weed seeds introduced into outdoor composting operations may remain viable in the finished compost, resulting in problematic weed pressure. While the presence of weeds may or may not affect the yield of crops, they can negatively affect the aesthetics of transplants grown for sale and demand more labor to remove the weeds from the flats. Pasteurization (partial elimination of microbes) or sterilization (complete elimination of microbes) could be used to reduce viable weed seeds and pathogens in composts. However, beneficial soil organisms may also be reduced at higher treatment temperatures, and chemicals that negatively affect plant growth may be produced when the treatment temperature reaches around $100{ }^{\circ} \mathrm{C}$ [9].

This study was conducted at Berea College Farm in Madison County, Kentucky, United States (USA). Berea College Farm is one of the oldest, continuously operating student farms in the USA, with a horticultural enterprise consisting of about 3 ha of fields, two heated greenhouses, and eight unheated high tunnels. The horticulture area began transitioning to organic production in 1998, and currently, all plant products produced on the farm are USDA Certified Organic. Typically, commercial peat-based potting media is used to start seeds in greenhouses. After the plants germinate, feather meal (FM) is added as a fertilizer. The farm manager has noted that while the combination of the peat-based potting media and FM seem to work well for some crops, such as lettuce, kale, and arugula, other crops, including spinach, beets, tomatoes, and peppers, had sometimes shown relatively poor germination and growth. While there are multiple possible causes for the poor germination rate and growth of these crops, the composition of the potting media and the availability of nutrients could have contributed at least partially to the diminished plant growth.

The goal of this research was to evaluate compost produced on-farm as a partial or complete potting medium substitute for the peat-based commercial products currently in use. Berea College Farm collects and processes food residuals from the dining service and other facilities on campus to produce compost. Wood chips deposited by local tree maintenance companies serve as the bulking agent. In 2002, a study was conducted at the farm evaluating the performance of the food-residuals compost for growing lettuce and tatsoi, concluding that food-residuals compost was a viable substitute for commercial peat-based potting media, although it was more expensive than the peat-based potting media [7].

This study includes two experiments performed in 2021 aimed at assessing the potential viability of farm-produced, food-residuals compost as a replacement for peat-based potting media in the production of organic vegetable transplants. The first objective was to compare seedling growth in the compost to that in various commercial peat-based potting media with different material and nutrient compositions. Beet (Beta vulgaris L.) was used as the test crop for this experiment. A second experiment was carried out to compare possible solutions to the presence of viable weed seeds in the compost. The objective of this experiment was to compare the effects of two compost treatment methodssterilization and pasteurization-on weed abundance and the crop growth of tomato (Solanum lycopersicum L.). 


\section{Materials and Methods}

\subsection{Experiment 1-Potting Media Comparison}

The first experiment was carried out in a heated greenhouse and a field at Berea College Farm between February 2021 and June 2021. The potting-media substrates evaluated in this study are listed in Table 1, which included: Food-residuals compost processed at Berea College Farm (C); a commercial peat-based potting medium (Pro-Mix MP Mycorrhizae Organik, Premier Tech, QC, Canada); and a commercial peat-based seed starting mix (Baccto Organic Optimum Seed Starting Mix, Michigan Peat Company, Houston, TX, USA). The commercial peat-based potting medium (P) contained $60-70 \%$ Sphagnum peat moss, horticultural coir, perlite, mycorrhizae, and limestone. The commercial peat-based seed starting mix (Baccto) contained Sphagnum peat moss, perlite, organic slow release fertilizer (derived from aerobically composted turkey litter, hydrolyzed FM, and sulfate of potash), and limestone. Additional fertilizers used in the treatments included FM (NPK, 13-0-0), a commercial slow-release fertilizer for micronutrients (Azomite, Azomite Mineral Products, Inc., Nephi, UT, USA), a commercial pelleted fertilizer derived from chicken manure (Italpollina Organic Fertilizer Pellets 4-4-4, Hello Nature USA, Inc., Anderson, IN, USA). The eight treatments were prepared as shown in Table 1. For T3 ( $25 \%$ C), T4 $(50 \% \mathrm{C})$, and T5 (75\% C), potting-media substrates were mixed by volume based on the respective ratio. For treatments that included Azomite, granulated Azomite was applied at the recommended rate of $4.2 \mathrm{~kg} / \mathrm{m}^{3}\left(7 \mathrm{lbs} / \mathrm{yard}^{3}\right)$. For T2 (P + FM), which was included to replicate the procedure currently used at Berea College Farm to grow transplants, $60 \mathrm{~mL}$ of FM were added to each flat 21 days after seeding. Macronutrient contents of each potting medium were calculated based on the soil testing results of the food-residuals compost (A \& L Western Agricultural Laboratories, Modesto, CA, USA) and on the product information of the commercial materials.

Table 1. Composition of potting media substrates and fertilizer used for each treatment.

\begin{tabular}{|c|c|c|}
\hline $\begin{array}{c}\text { Treatment } \\
\text { Description and Abbreviation }\end{array}$ & $\begin{array}{c}\text { Composition of Potting } \\
\text { Media Substrates }\end{array}$ & Added Fertilizer \\
\hline $\mathrm{T} 1(\mathrm{P})$ & 100\% Pro-Mix (P) & None \\
\hline $\mathrm{T} 2(\mathrm{P}+\mathrm{FM})$ & 100\% Pro-Mix & Feather meal (FM) ${ }^{1}$ \\
\hline T3 $(25 \%$ C $)$ & $75 \%$ Pro-Mix $+25 \%$ Compost $(\mathrm{C})$ & Azomite ${ }^{2}$ \\
\hline $\mathrm{T} 4(50 \% \mathrm{C})$ & $50 \%$ Pro-Mix $+50 \%$ Compost & Azomite \\
\hline T5 $(75 \% \mathrm{C})$ & $25 \%$ Pro-Mix $+75 \%$ Compost & Azomite \\
\hline T6 $(100 \% \mathrm{C})$ & $100 \%$ Compost & Azomite \\
\hline $\mathrm{T} 7(\mathrm{P}+\mathrm{CM})$ & $100 \%$ Pro-Mix & Italpollina $(\mathrm{CM})^{3}+$ Azomite \\
\hline T8 (Baccto) & $100 \%$ Baccto & None \\
\hline
\end{tabular}

${ }^{1} 60 \mathrm{~mL}$ of powdered feather meal was added to each flat 21 days following seeding. ${ }^{2}$ Azomite was added to the potting media at the recommended rate of $4.2 \mathrm{~kg} / \mathrm{m}^{3}\left(7 \mathrm{lbs} / \mathrm{yd}^{3}\right) .{ }^{3}$ Italpollina was added to Pro-Mix at 100:1 ratio by volume.

The experimental unit was a plastic 50-square-plug horticultural flat $(50 \mathrm{~cm}$ by $26 \mathrm{~cm}$ by $6 \mathrm{~cm}$ ). The volume of each plug was $85.5 \mathrm{~mL}$. On 21 February, 2021, 3-6 'Boro F1' beet seeds (Johnny's Selected Seeds, Winslow, ME, USA) were sown in each plug to a $13 \mathrm{~mm}$ ( $0.5 \mathrm{inch})$ depth and covered with horticultural vermiculite. For each of the eight treatments, five replications were made. All flats were placed on a table in the greenhouse in a completely randomized design.

Two plugs randomly selected from each flat were used as samples 36 days after seeding. Soil around the roots was gently removed with water. The following morphological attributes were recorded for each sample: The number of plants per plug; fresh and dry weight of shoots $(\mathrm{g})$; fresh and dry weight of roots $(\mathrm{g})$; the number of true leaves per plug, leaf width $(\mathrm{mm})$, and shoot length $(\mathrm{mm})$. For leaf width, a medium-sized leaf was selected from each plug, and the widest part of the blade was measured. For shoot length, a well-developed true leaf was selected from each sample plug, and the length from the bottom of the stem to the tip of the blade was measured. The mean values derived from two sample plugs from the same flat were used to represent the single replication. The 
number of weed seedlings in each flat was recorded 45 days after seeding. Qualitative observations of growth and leaf colors were made weekly.

Beginning 36 days after seeding, all treatments received liquid fertilizer (Allganic Nitrogen Plus 15-0-2, SQM S.A., Santiago, Chile). Stock solution was prepared at the rate of $363 \mathrm{~g} / 3.8 \mathrm{~L}(0.8 \mathrm{lbs} / \mathrm{gal})$, and applied through the irrigation water once a week. Fifty-seven days after seeding, one plug was randomly selected from each flat and transplanted into the field plot in a completely randomized design with a $30 \mathrm{~cm}$ by $30 \mathrm{~cm}(1 \mathrm{ft}$ by $1 \mathrm{ft})$ spacing per plant. The size of the experimental plot was $6.3 \mathrm{~m}$ by $1.6 \mathrm{~m}(20.7 \mathrm{ft}$ by $5.2 \mathrm{ft})$. The plot was irrigated with a single drip-irrigation tape. The plants were harvested 55 days after transplanting (114 days after seeding). After removing soil from the roots, the number of plants per sample, total weight of plants per sample (g), weight of roots (g), and weight of leaves (g) were recorded. The harvest index was calculated based on the total weight per sample and the weight of roots. For ease of comparison with other studies, mean root weights of each treatment are presented as yield per hectare.

\subsection{Experiment 2-Hear Treatments of Compost}

The second experiment was conducted in a heated greenhouse on the Berea College Farm, beginning in April 2021. Food-residuals compost processed on the farm was used as the medium for all treatments. For the control group, the compost was sifted and used without any further treatment. A pasteurization treatment and a sterilization treatment were prepared based on procedures described by Lamont et al. [10] and Arancibia [11]. For the pasteurization treatment, the temperature of sifted compost was raised in an oven to $77^{\circ} \mathrm{C}\left(170^{\circ} \mathrm{F}\right)$, maintained at that temperature for $30 \mathrm{~min}$, then allowed to cool. For the sterilization treatment, the temperature of sifted compost was raised to $100{ }^{\circ} \mathrm{C}\left(21{ }^{\circ} \mathrm{F}\right)$ in a pressure cooker, then allowed to cool. A 72 square-plug horticultural flat $(53 \mathrm{~cm}$ by $26 \mathrm{~cm}$ by $6 \mathrm{~cm}$ ) was used as an experimental unit. Each flat was filled with the appropriate compost, and a single seed of 'Black Krim' tomato (Johnny's Selected Seeds, Winslow, ME, USA) was planted in each cell on 12 April 2021. Four replications were made for each experimental group. The flats were arranged randomly on a single table in the greenhouse and watered equally as needed. Germination rate and weed abundance were recorded for each flat on 19 April, 23 April, and 26 April. The fresh plant weight of tomato seedlings was recorded on 7 May, when the plants were ready for transplanting. Two plants were taken from each flat as samples, and each plant was weighed after the compost was gently removed from the roots. Mean weight of two plants per flat was used to represent the single replication.

\subsection{Statistical Analysis}

Quantitative data were analyzed using single factor analysis of variance (ANOVA). Significance was defined as $p \leq 0.05$, and the least significant difference (LSD) method was used to determine differences among treatments when the ANOVA indicated statistical significance $(p \leq 0.05)$.

\section{Results}

\subsection{Experiment 1-Potting Media Comparison}

The different potting-media treatments had significant effects on the growth of beet transplants. Based on the fresh and dry weights of shoots recorded 36 days after seeding, the shoot weight became progressively greater with increasing amounts of compost in the medium (Table 2). Specifically, mean fresh and dry shoot weight of T4 $(50 \% \mathrm{C})$ was significantly greater than that of T1 (P), T2 (P + FM), T3 (25\% C), and T8 (Baccto). The mean fresh and dry shoot weight was significantly greater in $\mathrm{T} 5(75 \% \mathrm{C})$ than $\mathrm{T} 4(50 \% \mathrm{C})$, and in T6 $(100 \% \mathrm{C})$ than T5 $(75 \% \mathrm{C})$. T7 $(\mathrm{P}+\mathrm{CM})$ had a mean fresh and dry shoot weight similar to that of $\mathrm{T} 4(50 \% \mathrm{C})$. Based on the fresh and dry root weights, differences were not significant between T5 $(75 \% \mathrm{C})$ and T6 $(100 \% \mathrm{C})$. The mean dry root weight of T7 (P + CM) 
was significantly higher than any other treatment, and that of T2 (P + FM), T4 (50\% C), T5 $(75 \%$ C), T6 (100\% C), and T8 (Baccto) were not significantly different from each other.

Table 2. Effect of different potting media treatments on the weight of beet seedlings, 36 days following seeding $(n=5)$.

\begin{tabular}{|c|c|c|c|c|}
\hline Treatment & $\begin{array}{l}\text { Fresh Weight of } \\
\text { Shoots (g/Plant) }{ }^{1}\end{array}$ & $\begin{array}{l}\text { Dry Weight of } \\
\text { Shoots (g/Plant) }\end{array}$ & $\begin{array}{l}\text { Fresh Weight of } \\
\text { Roots (g/Plant) }\end{array}$ & $\begin{array}{l}\text { Dry Weight of } \\
\text { Roots (g/Plant) }\end{array}$ \\
\hline $\mathrm{T} 1(\mathrm{P})$ & $0.231^{\mathrm{f}}$ & $0.029^{\mathrm{e}}$ & $0.181^{\mathrm{c}}$ & $0.030^{\mathrm{d}}$ \\
\hline $\mathrm{T} 2(\mathrm{P}+\mathrm{FM})$ & $0.596^{d}$ & $0.057^{\mathrm{d}}$ & $0.326^{b}$ & $0.046^{b c d}$ \\
\hline $\mathrm{T} 3(25 \% \mathrm{C})$ & $0.465^{\text {de }}$ & $0.061^{\mathrm{d}}$ & $0.287^{b}$ & $0.035^{\mathrm{cd}}$ \\
\hline $\mathrm{T} 4(50 \% \mathrm{C})$ & $0.776^{c}$ & $0.096^{c}$ & $0.442^{\mathrm{a}}$ & $0.055^{b}$ \\
\hline T5 (75\% C) & $0.990^{b}$ & $0.122^{b}$ & $0.338^{b}$ & $0.049 \mathrm{bc}$ \\
\hline T6 (100\% C) & $1.256^{\mathrm{a}}$ & $0.144^{\mathrm{a}}$ & $0.429^{a}$ & $0.061^{b}$ \\
\hline $\mathrm{T} 7(\mathrm{P}+\mathrm{CM})$ & $0.803^{\mathrm{c}}$ & $0.081^{\mathrm{c}}$ & $0.471^{\mathrm{a}}$ & $0.070^{a}$ \\
\hline T8 (Baccto) & $0.325^{\text {ef }}$ & $0.053^{\mathrm{d}}$ & $0.237^{\mathrm{c}}$ & $0.052^{b}$ \\
\hline$p$-value & $p<0.001$ & $p<0.001$ & $p<0.001$ & $p<0.001$ \\
\hline
\end{tabular}

${ }^{1}$ Values accompanied by different letters indicate significant differences $(p \leq 0.05)$ based on LSD method.

The number of true leaves per plant, the length of shoots, and the width of leaves recorded 36 days after seeding showed overall trends similar to the fresh and dry weight of shoots (Table 3$)$. In all three measurements, T6 $(100 \%$ C) had significantly higher mean value compared to any other treatment, and $\mathrm{T} 5(75 \% \mathrm{C})$ had a mean value significantly higher than any other treatment except for that of T6 $(100 \%$ C). T8 (Baccto) performed similarly to $\mathrm{T} 2(\mathrm{P}+\mathrm{FM})$ and $\mathrm{T} 3(25 \% \mathrm{C})$, where the mean values were significantly smaller than that of T5 $(75 \%$ C) and T6 $(100 \%$ C). For the length and the width of leaves, the mean values for T8 (Baccto) was also significantly smaller than T4 (50\% C).

Table 3. Effect of different potting media treatments on the growth of beet seedlings, 36 days following seeding $(n=5)$.

\begin{tabular}{cccc}
\hline Treatment & $\begin{array}{c}\text { Number of True } \\
\text { Leaves per Plant }^{\mathbf{1}}\end{array}$ & $\begin{array}{c}\text { Length of Shoots } \\
(\mathbf{m m})\end{array}$ & $\begin{array}{c}\text { Width of Leaves } \\
(\mathbf{m m})\end{array}$ \\
\hline T1 (P) & $3.0^{\mathrm{f}}$ & $36.9^{\mathrm{f}}$ & $6.2^{\mathrm{f}}$ \\
T2 (P + FM) & $4.4^{\mathrm{cd}}$ & $60.9^{\mathrm{d}}$ & $13.9^{\mathrm{e}}$ \\
T3 $(25 \% \mathrm{C})$ & $3.7^{\mathrm{e}}$ & $46.5^{\mathrm{e}}$ & $13.2^{\mathrm{e}}$ \\
T4 $(50 \% \mathrm{C})$ & $4.6^{\mathrm{bcd}}$ & $66.5^{\mathrm{cd}}$ & $19.3^{\mathrm{c}}$ \\
T5 (75\% C) & $5.1^{\mathrm{b}}$ & $88.0^{\mathrm{b}}$ & $22.8^{\mathrm{b}}$ \\
T6 (100\% C) & $5.9^{\mathrm{a}}$ & $104.7^{\mathrm{a}}$ & $27.6^{\mathrm{a}}$ \\
T7 (P + CM) & $4.2^{\mathrm{cde}}$ & $70.8^{\mathrm{c}}$ & $17.1^{\mathrm{d}}$ \\
T8 (Baccto) & $3.8^{\mathrm{de}}$ & $50.0^{\mathrm{e}}$ & $13.8^{\mathrm{e}}$ \\
\hline$p$-value & $p<0.001$ & $p<0.001$ & $p<0.001$ \\
\hline
\end{tabular}

${ }^{1}$ Values accompanied by different letters indicate significant differences ( $\left.p \leq 0.05\right)$ based on LSD method.

As shown in Table 4, the mean number of weed seedlings was significantly higher in any treatment that contained more than $50 \%$ of compost (T4, T5 and T6) compared to T3 $(25 \% \mathrm{C})$. Those that did not contain any compost (T1, T2, T7 and T8) did not have any weed seedlings, as expected. While a few German chamomile (Matricaria chamomilla L.) seedlings were observed in $\mathrm{T} 1(\mathrm{P})$ and $\mathrm{T} 2(\mathrm{P}+\mathrm{FM})$, it is likely that the seeds contaminated the potting media in the greenhouse rather than in the processing facility, as German chamomile plants were grown in the same greenhouse where the experiment was carried out. 
Table 4. Effect of different potting media treatments on the weed pressure, 45 days following seeding $(n=5)$.

\begin{tabular}{cc}
\hline Treatment & Number of Weed Seedlings per Flat ${ }^{\mathbf{1}}$ \\
\hline T1 (P) & $0.2^{\mathrm{c}}$ \\
T2 (P + FM) & $0.6^{\mathrm{c}}$ \\
T3 (25\% C) & $8.2^{\mathrm{b}}$ \\
T4 (50\% C) & $13.8^{\mathrm{a}}$ \\
T5 (75\% C) & $13.4^{\mathrm{a}}$ \\
T6 (100\% C) & $15.0^{\mathrm{a}}$ \\
T7 (P + CM) & $0.0^{\mathrm{c}}$ \\
T8 (Baccto) & $0.0^{\mathrm{c}}$ \\
\hline$p$-value & $p<0.001$ \\
\hline
\end{tabular}

${ }^{1}$ Values accompanied by different letters indicate significant differences $(p \leq 0.05)$ based on LSD method.

Based on the soil testing results, total nitrogen content of the compost used in this experiment was $1.78 \%$, phosphate content was $0.08 \%$, and soluble potash content was $0.39 \%$ (Table 5). Macronutrient contents of T8 (Baccto) were lower than the estimated macronutrient contents of any treatment that contained compost (T3, T4, T5, and T6). Discoloration of leaves was first observed in T3 (25\% C) 21 days following seeding. After 36 days from seeding, as seen in Figure 1, discoloration was especially severe for T1 (P), T3 $(25 \% \mathrm{C})$, and T8 (Baccto). In T2 (P + FM), leaves retained darker shades of green. In T5 (75\% C), T6 (100\% C), and T7 (P + CM), leaf discoloration was generally less severe than in T1 (P), T3 (25\% C), and T8 (Baccto).

Table 5. Estimated macronutrient contents of each potting media treatment. T1 (P) and T8 (Baccto) are based on the product description. T2 $(\mathrm{P}+\mathrm{FM})$ and $\mathrm{T} 7(\mathrm{P}+\mathrm{CM})$ are based on the product description of the fertilizers and the measured weight of Pro-Mix (Peat). T6 $(100 \% \mathrm{C})$ is based on the soil test results of compost reported on April 12, 2021 (A \& L Western Agricultural Laboratories, Modesto, CA, USA). T3 (25\% C), T4 $(50 \% \mathrm{C})$, and T5 (75\% C) are based on the soil test results of compost and the measured weights of potting media substrates.

\begin{tabular}{cccc}
\hline Treatment & Total Nitrogen (\%) & $\begin{array}{c}\text { Phosphate (\%) } \\
\mathbf{P}_{2} \mathbf{O}_{5}\end{array}$ & $\begin{array}{c}\text { Soluble Potash (\%) } \\
\mathbf{K}_{2} \mathbf{O}\end{array}$ \\
\hline T1 (P) & 0 & 0 & 0 \\
T2 (P+FM) & 0.336 & 0 & 0 \\
T3 (25\% C) & 0.826 & 0.469 & 0.181 \\
T4 (50\% C) & 1.29 & 0.729 & 0.282 \\
T5 (75\% C) & 1.58 & 0.895 & 0.346 \\
T6 (100\% C) & 1.78 & 1.01 & 0.39 \\
T7 (P + CM) & 0.094 & 0.094 & 0.094 \\
T8 (Baccto) & 0.6 & 0.08 & 0.04 \\
\hline
\end{tabular}

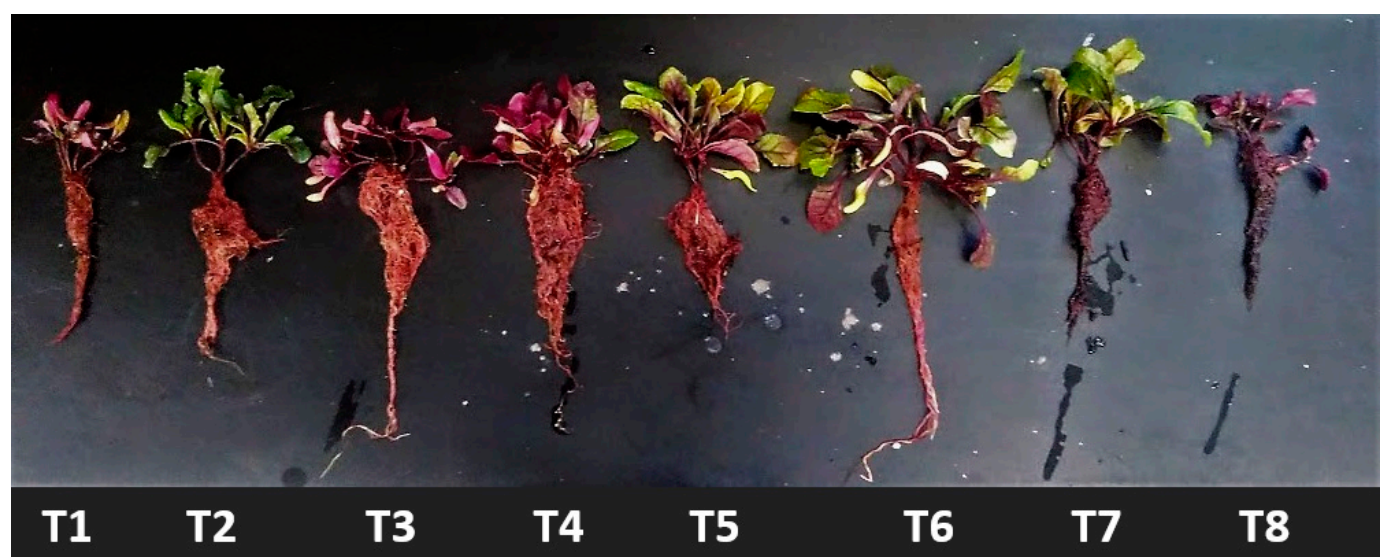

Figure 1. Effect of potting-media treatments on beet seedling growth, 36 days after seeding. 
Based on the plant weight recorded 55 days after transplanting beet seedlings, T8 (Baccto) had significantly lower root weight than all the other treatments except for T3 (25\% C; Table 6). Mean weight of leaf and the harvest index did not differ significantly among different treatments $(p>0.05)$. Estimated yield ranged from $7.65 \mathrm{t} /$ ha for T8 (Baccto) up to $16.99 \mathrm{t} /$ ha for T6 $(100 \%$ C; Table 7$)$.

Table 6. Effect of different potting media treatments on beet yields 55 days after transplanting, or 114 days following seeding $(n=5)$.

\begin{tabular}{ccccc}
\hline Treatment & $\begin{array}{c}\text { Total Plant Weight per } \\
\text { Sample }(\mathbf{g})^{\mathbf{1}}\end{array}$ & $\begin{array}{c}\text { Total Root Weight per } \\
\text { Sample (g) }\end{array}$ & $\begin{array}{c}\text { Total Leaf Weight per } \\
\text { Sample (g) }\end{array}$ & Harvest Index \\
\hline T1 (P) & $544.2^{\mathrm{a}} \pm 116.8$ & $342.0^{\mathrm{a}} \pm 78.1$ & $202.2 \pm 42.6$ & $0.622 \pm 0.025$ \\
T2 (P + FM) & $610.0^{\mathrm{a}} \pm 51.6$ & $371.0^{\mathrm{a}} \pm 22.9$ & $239.0 \pm 31.1$ & $0.613 \pm 0.019$ \\
T3 (25\% C) & $446.8^{\mathrm{ab}} \pm 69.9$ & $302.8^{\mathrm{ab}} \pm 40.3$ & $144.0 \pm 35.1$ & $0.690 \pm 0.040$ \\
T4 (50\% C) & $512.0^{\mathrm{a}} \pm 22.5$ & $316.4^{\mathrm{a}} \pm 22.9$ & $195.6 \pm 10.0$ & $0.616 \pm 0.022$ \\
T5 (75\% C) & $643.8^{\mathrm{a}} \pm 25.0$ & $425.6^{\mathrm{a}} \pm 35.2$ & $218.2 \pm 19.5$ & $0.658 \pm 0.035$ \\
T6 $(100 \% \mathrm{C})$ & $651.2^{\mathrm{a}} \pm 44.2$ & $428.2^{\mathrm{a}} \pm 33.2$ & $223.0 \pm 17.2$ & $0.657 \pm 0.018$ \\
T7 $(\mathrm{P}+\mathrm{CM})$ & $574.4^{\mathrm{a}} \pm 28.4$ & $399.2^{\mathrm{a}} \pm 25.7$ & $175.2 \pm 20.3$ & $0.696 \pm 0.031$ \\
T8 (Baccto) & $327.8^{\mathrm{b}} \pm 36.1$ & $192.8^{\mathrm{b}} \pm 28.5$ & $135.0 \pm 10.1$ & $0.578 \pm 0.029$ \\
\hline$p$-value & 0.005 & 0.004 & 0.071 & 0.077 \\
\hline
\end{tabular}

Table 7. Estimated yield of beets in metric ton per hectare, based on the total root weight per sample and the plot size $(n=5)$.

\begin{tabular}{cc}
\hline Treatment & Estimated Yield (t/ha) ${ }^{\mathbf{1}}$ \\
\hline T1 (P) & $13.57^{\mathrm{a}} \pm 3.10$ \\
T2 (P + FM) & $14.72^{\mathrm{a}} \pm 0.91$ \\
T3 (25\% C) & $12.02^{\mathrm{ab}} \pm 1.60$ \\
T4 (50\% C) & $12.56^{\mathrm{a}} \pm 0.91$ \\
T5 (75\% C) & $16.89^{\mathrm{a}} \pm 1.40$ \\
T6 (100\% C) & $16.99^{\mathrm{a}} \pm 1.32$ \\
T7 (P + CM) & $15.84^{\mathrm{a}} \pm 1.02$ \\
T8 (Baccto) & $7.65^{\mathrm{b}} \pm 1.13$ \\
\hline p-value & 0.004 \\
\hline
\end{tabular}

${ }^{1}$ Values accompanied by different letters indicate significant differences $(p \leq 0.05)$ based on LSD method.

\subsection{Experiment 2-Heat Treatments of Compost}

While the sterilization-treatment group had a significantly lower crop germination rate than the control and pasteurization-treatment groups based on the data collected on 19 April (7 days after seeding), there were no significant differences in germination rate among different treatments 11 days following seeding (Table 8). By this time, all three experimental groups had a germination rate of more than $90 \%$. Weed abundance was significantly reduced by sterilization treatment, which had no weed emergence (Table 9). On the other hand, there were no significant differences in the weed abundance observed between control group and pasteurization treatment. Plant growth measured by the fresh weight of whole plants was not significantly affected by sterilization or pasteurization treatments (Table 10). 
Table 8. Effects of compost treatments on the germination rate of tomato seedlings $(n=4)$. Tomato seeds were planted on 12 April 2021.

\begin{tabular}{cccc}
\hline \multirow{2}{*}{ Experimental Group } & & Crop Germination Rate (\%) & \\
& 19 April 2021 $^{\mathbf{1}}$ & 23 April 2021 & 26 April 2021 \\
\hline Control & $45.3^{\mathrm{a}}$ & 67.3 & 67.8 \\
Pasteurization & $51.5^{\mathrm{a}}$ & 69.5 & 70.3 \\
Sterilization & $17.3^{\mathrm{b}}$ & 68.0 & 69.8 \\
\hline$p$-value & 0.002 & 0.348 & 0.344 \\
\hline
\end{tabular}

${ }^{1}$ Values accompanied by different letters indicate significant differences $(p \leq 0.05)$ based on LSD method.

Table 9. Effects of compost treatments on the weed abundance $(n=4)$. Tomato seeds were planted on 12 April 2021.

\begin{tabular}{cccc}
\hline \multirow{2}{*}{ Experimental Group } & \multicolumn{3}{c}{ Number of Weed Seedlings per Flat } \\
& 19 April 2021 & 23 April 2021 & 26 April 2021 \\
\hline Control & $25.8^{\mathrm{a}}$ & $49.8^{\mathrm{a}}$ & $41.8^{\mathrm{a}}$ \\
Pasteurization & $27.5^{\mathrm{a}}$ & $40.3^{\mathrm{a}}$ & $41.5^{\mathrm{a}}$ \\
Sterilization & $0^{\mathrm{b}}$ & $0^{\mathrm{b}}$ & $0^{\mathrm{b}}$ \\
\hline$p$-value & $p<0.001$ & $p<0.001$ & $p<0.001$ \\
\hline
\end{tabular}

${ }^{1}$ Values accompanied by different letters indicate significant differences $(p \leq 0.05)$ based on LSD method.

Table 10. Effects of compost treatments on the fresh weight of tomato seedlings 26 days following seeding $(n=4)$. Values are given as the mean \pm standard error.

\begin{tabular}{cc}
\hline Experimental Group & Mean Plant Weight (g) \\
\hline Control & $4.14 \pm 0.566$ \\
Pasteurization & $4.03 \pm 0.591$ \\
Sterilization & $4.53 \pm 0.409$ \\
\hline$p$-value & 0.787 \\
\hline
\end{tabular}

\section{Discussion}

The objective of the first experiment was to compare and evaluate the performance of multiple potting-media treatments utilizing peat and food-residuals compost as the main substrates, using beet as the test crop. The results of the experiment were consistent with previous studies [6,7], indicating that $75 \%$ to $100 \%$ of food-residuals compost used in potting media could perform as well as fertilized peat-based growing media for plant growth. In this study, treatments containing more than $75 \%$ compost (T5 and T6) resulted in improved plant growth compared to commercially available peat-based potting media with various added fertilizers (T2, T7 and T8). The amounts of available nitrogen in the media likely affected the observed difference in plant growth. As shown in Table 5, the amount of total nitrogen in T8 (Baccto) was more than that in T3 (25\% C), but less than that in T4 $(50 \% \mathrm{C})$; which corresponds with the plant growth measurements where T8 (Baccto) performed similarly to T3 $(25 \% \mathrm{C})$ and T4 $(50 \% \mathrm{C})$. Since the micronutrient contents of fertilized peat-based potting media treatments were less than that of treatments with high amount of compost, seedling growth was likely limited in the fertilized peat-based potting media treatments. However, based on previous studies [6,7], it is possible that the peat-based potting media would perform as well as compost-containing media if sufficient amounts of nutrients are added to the media.

According to a study by Salahas et al. [12] on red beet (B. vulgaris), the plants grown under nitrogen-limited conditions had $28 \%$ less leaf chlorophyll content and tended to have red violet leaves, while those that had sufficient nitrogen had green leaves with red violet veins. The discoloration of leaves observed in T1 (P), T3 $(25 \% \mathrm{C}), \mathrm{T} 4(50 \% \mathrm{C})$, and T8 (Baccto) in this study was likely due to the nitrogen deficiency. Despite the significantly greater number of weed seedlings observed in treatments that contained more than $50 \%$ of 
compost, beet seedlings had greater growth in those treatments, indicating that the higher weed pressure did not affect crop growth negatively.

While the growth of beet transplants was affected by the composition of potting media, the beet yields did not significantly differ among different treatments except for T8 (Baccto), which had significantly lower root weight. These results indicate that shoot and root biomass of beet transplants had little effect on the root weight at harvest when they are transplanted into the same field environment. The differences among the treatments could have also been reduced due to the liquid fertilizer added to all experimental flats between 36 days after seeding and the date of transplanting ( 57 days after seeding). Compared to the yields of organic beets reported in other studies which range from 15.7 to $53.28 \mathrm{t} / \mathrm{ha}$ [13-16], estimated yields in this study were on the lower end. This may have been due to the differences in plant spacing, seeding and thinning methods, and climate. Based on a peer-reviewed report from California [13], the estimated yields of T5 $(75 \% \mathrm{C}), \mathrm{T} 6(100 \% \mathrm{C})$, and $\mathrm{T} 7(\mathrm{P}+\mathrm{CM})$ were slightly above the average.

The objective of the second experiment was to compare the effects of sterilization and pasteurization on the weed abundance and the growth of tomato transplants grown in foodresiduals compost. The results of the second experiment showed that sterilization treatment of compost at $100{ }^{\circ} \mathrm{C}\left(212^{\circ} \mathrm{F}\right)$ effectively eliminated viable weed seeds. Pasteurization treatment, on the other hand, did not reduce the weed abundance compared to untreated compost. While Byther and Davidson [9] mentioned potential adverse effects on the plant growth caused by toxic chemical substances produced at the high temperature required for sterilization, no significant effect on the tomato plant growth was observed in this experiment. However, sterilization did lead to slower germination of tomato seedlings, which may have been caused by the presence of such toxic chemical substances. There is also a possibility that some beneficial microbes or chemical substances had been eliminated by the sterilization treatment, leading to the slower plant germination. Further study would be necessary to determine the exact mechanism by which the plant germination was slowed through sterilization.

Despite the initial delay in germination, the mean plant weight in sterilization treatment group recorded 26 days after seeding was not significantly different from the control or pasteurization-treatment group. The results indicate that (1) weed pressure was not significant enough to adversely affect the growth of tomato plants; and (2) sterilization treatment did not result in reduced plant growth. There is also a slight possibility that the adverse effects of weed pressure and sterilization caused similar rates of reduction in plant growth. Further studies would be necessary to determine whether that is the case. For production purposes, all treatments resulted in an acceptable rate of plant growth. Therefore, sterilization would be recommended only when aesthetics is an important factor for the plant production, such as when producing ornamental plants or transplants for sale. At least for growing tomato seedlings for crop production, sterilization of compost does not appear necessary as the growth of transplants were not negatively affected by the abundance of weeds in untreated compost. Based on the results of this study, pasteurizing compost at $77^{\circ} \mathrm{C}\left(170^{\circ} \mathrm{F}\right)$ for $30 \mathrm{~min}$ would not be recommended for the purpose of reducing weed pressure as it had no significant effects on either weed abundance or the plant growth.

In conclusion, food-residuals compost appears to be a viable option for replacing horticultural peat as the main substrate of potting media to grow organic transplants in greenhouses. Despite the presence of weed seeds and higher weed pressure, potting media that contained $75-100 \%$ food-residuals compost performed as well as or better than peat-based potting media fertilized with different kinds of organic fertilizers in terms of the seedling growth and final yields.

Author Contributions: Conceptualization, T.I., S.C. and J.M.; methodology, T.I. and S.C.; formal analysis, T.I. and S.C.; writing—original draft preparation, T.I.; writing—review and editing, S.C. All authors have read and agreed to the published version of the manuscript. 
Funding: This research received no external funding.

Acknowledgments: The authors recognize the following people for their assistance with field work and data collection: Aazan Ahmad, Elijah Browning, Jocelyn Lee, Noah Reasoner, Miriam Styer, Victor Faluyi, and Hallie Whitehead.

Conflicts of Interest: The authors declare no conflict of interest.

\section{References}

1. Schmilewski, G. The role of peat in assuring the quality of growing media. Mires Peat 2008, 3, 2.

2. Alexander, P.D.; Bragg, N.C.; Meade, R.; Padelopoulos, G.; Watts, O. Peat in horticulture and conservation: The UK response to a changing world. Mires Peat 2008, 3, 8 .

3. Schroder, C.; Dahms, T.; Paulitz, J.; Wichtmann, W.; Wichmann, S. Towards large-scale paludiculture: Addressing the challenges of biomass harvesting in wet and rewetted peatlands. Mires Peat 2015, 16, 13.

4. Dargie, G.; Lewis, S.; Lawson, I.; Edward, M.T.A.; Susan, P.E.; Yannick, B.E.; Suspense, I.A. Age, extent and carbon storage of the central Congo Basin peatland complex. Nature 2017, 542, 86-90. [CrossRef]

5. Boldrin, A.; Hartling, K.R.; Laugen, M.; Christensen, T.H. Environmental inventory modelling of the use of compost and peat in growth media preparation. Resour. Conserv. Recycl. 2010, 54, 1250-1260. [CrossRef]

6. Farrell, M.; Jones, D.L. Food waste composting: Its use as a peat replacement. Waste Manag. 2010, 30, 1495-1501. [CrossRef] [PubMed]

7. Clark, S.; Cavigelli, M. Suitability of composts as potting media for production of organic vegetable transplants. Compost Sci. Util. 2005, 13, 150-156. [CrossRef]

8. Lazcano, C.; Arnold, J.; Tato, A.; Zaller, J.G.; Domínguez, J. Compost and vermicompost as nursery pot components: Effects on tomato plant growth and morphology. Span. J. Agric. Res. 2009, 7, 944-951. [CrossRef]

9. Byther, R.; Davidson, R.M. Soil Treatment Procedures for the Home Gardener. Available online: https://research.libraries.wsu. edu/xmlui/handle/2376/6690 (accessed on 28 June 2021).

10. Lamont, P.; Kelley, K.M.; Sellmer, J.C. How to Pasteurize Medium and Sterilize Containers and Tools. Available online: https:/ / extension.psu.edu/how-to-pasteurize-medium-and-sterilize-containers-and-tools (accessed on 28 June 2021).

11. Arancibia, R.A. Soil Steaming to Reduce the Incidence of Soil-Borne Diseases, Weeds and Insect Pests. Available online: https: / ipm.missouri.edu/MPG/2020/11/steaming-RA/ (accessed on 28 June 2021).

12. Salahas, G.; Papasavvas, A.; Giannakopoulos, E.; Tselios, T.; Konstantopoulou, H.; Savvas, D. Impact of nitrogen deficiency on biomass production, leaf gas exchange, and betacyanin and total phenol concentrations in red beet (Beta vulgaris L. ssp. vulgaris) plants. Eur. J. Hortic. Sci. 2011, 76, 194-200.

13. Schrader, W.L.; Mayberry, K.S. Beet and Swiss Chard Production in California. Available online: https://anrcatalog.ucanr.edu/ pdf/8096.pdf (accessed on 6 July 2021).

14. Straus, S.; Bavec, F.; Turinek, M.; Slatnar, A.; Crtomir, R.; Bavec, M. Nutritional value and economic feasibility of red beetroot (Beta vulgaris L. ssp. vulgaris Rote Kugel) from different production systems. Afr. J. Agric. Res. 2012, 7, 5653-5660.

15. Szopińska, A.A.; Gawęda, M. Comparison of yield and quality of red beet roots cultivated using conventional, integrated and organic method. J. Hortic. Res. 2013, 21, 107-114. [CrossRef]

16. Yasaminshirazi, K.; Hartung, J.; Groenen, R.; Heinze, T.; Fleck, M.; Zikeli, S.; Graeff-Hoenninger, S. Agronomic performance of different open-pollinated beetroot genotypes grown under organic farming conditions. Agronomy 2020, 10, 812. [CrossRef] 